\title{
Basic levels of categorization: \\ A comparison of selected English and Polish verbs
}

\author{
OLGA SOKOŁOWSKA
}

\author{
Received 25.05.2020, \\ received in revised form 7.10.2020, \\ accepted 12.10.2020.
}

\begin{abstract}
The phenomenon of basic level concepts in cognition and categorization, so crucial in the cognitive account of natural language is typically accessed via what is perceptually the most outstanding phenomena represented in many languages, at least those rooted in Proto-IndoEuropean (specifically English and Polish) by nouns fulfilling the criteria of basic terms, originally established for classifying color vocabulary. These are prototypical examples in the category of nouns - relating to countable, material objects. Nominal representation, according to Langacker (1987) is indicative of a given stimulus being perceived and conceptualized as a thing, i.e., a region in one or more cognitive domains (conceptions) established in the speakers' minds. This is a rather self-imposing construal of physical, countable stimuli, which meet the good gestalt criteria, such as animals, plants, and man-made objects of everyday use. The semantic scopes of nouns representing such phenomena seem to overlap to a relatively high degree across languages, especially related ones, such as English and Polish, and finding the precise equivalents within them does not pose particular problems. This is hardly the case when it comes to phenomena represented by verbs and classifiable as processes in Langacker's cog-
\end{abstract}


nitive, semantic account of the division of words into parts of speech. A comparison of the meaning of selected basic English verbs and their closest Polish counterparts reveals serious discrepancies in a number of cases. Thus, certain basic English verbs representing common, everyday physical activities prove to differ considerably from their Polish counterparts with regard to their respective levels of schematicity/ specificity of meaning, and, in consequence, the range of cognitive domains involved in their semantic scopes. This is the case of such equivalent lexemes as płynać/pływać-swim; sail; flow; float or break - łamać; tłuc; rwać; drzeć. In both cases, one language is quite specific while the other is much more schematic as regards the actual cognitive domains activated by corresponding words and the degree to which that activation in the stimulated conceptual blends depends on the lexical context in which the respective words are used. This indicates that even related languages spoken by communities from similar cultural circles may codify considerably different construals of the same nonmaterial phenomena, specifically processes.

\title{
Keywords
}

basic levels of categorization, basic language terms, cognitive domains, equivalence

\section{Poziom podstawowy kategoryzacji: Porównanie wybranych czasowników w języku angielskim i polskim}

\begin{abstract}
Abstrakt
Zjawisko poziomu podstawowego w poznaniu i kategoryzacji, kluczowe dla kognitywnego podejścia do języka, zostało rozpoznane za pośrednictwem bytów najbardziej wyróżniających się w ludzkiej percepcji swiata, reprezentowanych w wielu językach, w tym tych o praindoeuropejskich korzeniach, jak angielski i polski, przez rzeczowniki spełniajace kryteria słownictwa podstawowego, pierwotnie ustalone dla celów klasyfikacji terminologii barw. Sa to przykłady prototypowe w kategorii rzeczowników - odnoszące się do policzalnych przedmiotów materialnych. Reprezentacja przez rzeczownik wskazuje, według Langa-
\end{abstract}


ckera, na konceptualizację danego bodźca jako rzeczy, czyli regionu w jednej lub kilku domenach kognitywnych (koncepcjach) ustalonych w umysłach użytkowników języka. Taka konceptualizacja wydaje się być raczej oczywista w przypadku bytów materialnych, policzalnych, posiadających wszystkie cechy dobrego gestaltu, takich, jak zwierzęta, rośliny, przedmioty codziennego użytku. Zakresy semantyczne rzeczowników funkcjonujących w różnych językach, szczególnie spokrewnionych, jak angielski i polski, które reprezentują takie byty zdają się być w dużym stopniu do siebie podobne, a znalezienie dokładnych odpowiedników w zestawieniu tych języków nie nastręcza szczególnych trudności. Takiej symetrii nie daje się jednak zauważyć w przypadku zjawisk opisywanych w obu językach przez czasowniki, klasyfikowanych jako procesy w kognitywnej, opartej na kryteriach semantycznych, Langackerowskiej klasyfikacji wyrazów jako części mowy. Porównanie znaczenia wybranych podstawowych czasowników angielskich ze znaczeniem polskich wyrazów uważanych za ich odpowiedniki ukazuje w wielu przypadkach istotne różnice. Niektóre powszechnie używane angielskie czasowniki podstawowe odnoszące się do codziennych czynności fizycznych różnią się znacznie od swoich polskich odpowiedników pod względem schematyczności lub specyficzności znaczenia i, co za tym idzie, także pod względem zestawu domen kognitywnych obejmowanych przez ich zakres semantyczny. Przykładami tego zjawiska sa takie ekwiwalenty leksykalne, jak np. płynać / pływać - swim, sail, flow, float or break - łamać, tłuc, rwać, drzeć. W obu przytoczonych przykładach jeden $z$ branych pod uwage języków odnosi się do danego procesu w sposób znacznie bardziej schematyczny/specyfikujący niż drugi - biorąc pod uwagę wybór i liczbę domen kognitywnych rozpoznawalnych w ich zakresach semantycznych, a także rolę kontekstu leksykalnego we wnoszeniu tych domen do stymulowanych amalgamatów pojęciowych. Wskazuje to na fakt, że nawet pokrewne języki używane przez społeczności pochodzące $z$ podobnych kręgów kulturowych moga konwencjonalizować znaczaco różne sposoby obrazowania tych samych bytów niematerialnych, szczególnie czynności.

\section{Słowa kluczowe}

podstawowe poziomy kategoryzacji, podstawowe terminy języka, domeny kognitywne, ekwiwalencja 
The purpose of this paper is to develop a new perspective in the outlook on a long-recognized and well-known issue - basic level categories in human cognition, whose psychological reality is corroborated by a specific kind of linguistic labels (basic terms) attached to them by speakers of different languages. What seems to deserve attention is the question of whether the crosslanguage symmetry observed with regard to specimens of natural life (plants, animals) symbolized by nominal expressions is maintained when it comes to more elusive categories (especially those which are typically referred to by means of verbs). An approximation at answering this question appears to be a comparison of the semantic scopes of certain predications functioning in two languages which are distinct but related by Proto-IndoEuropean roots: English and Polish.

The recognition of the phenomenon of basic levels in cognition emerged as part of a broader inquiry into the meaning and use of certain symbolic units (words) referring to cognitive stimuli constituted by material objects that exhibit good gestalt properties (fulfilling the criteria of proximity, similarity, closure, continuity), which predisposes them for the role of figures standing out against their backgrounds. Plant and animal terminology is especially attractive as an object of such studies because it concerns omnipresent phenomena of utmost interest to the members of any human community. Being able to correctly recognize and name such objects has always been an important issue in people's lives, irrespective of their culture and advancement in technological development.

The phenomenon in question was first described by Roger Brown in his classical paper "How shall a thing be called" published in 1958 (cf. Lakoff 1987:31). One of the leading researchers into human cognition, Eleanor Rosch (cf. Lakoff 1987: 3957 ) discovered that the basic level of categorization is connected with the fact that the human mind focuses on a certain number of outstanding and important properties of a phenomenon. This recognition ensures optimal effectiveness in classifying this phenomenon for relevant, practical purposes. The basic level is neither too general nor too specific, and concerns those categorical 
generalizations which are best suited for human perception, i.e. "human sized". These are by no means categories occupying the lowest positions determined by the vertical dimension of any categorization systems - whether of folk or scientific provenience. As observed by Evans (2019), basic level categories represent a certain degree of inclusiveness that is optimal for humans, this optimality being determined by average cognitive capacities of homo sapiens as well as by the most basic and universal biological needs of the representatives of the species. In the case of living organisms, this level has been found, by studying, among others, the vocabulary used by speakers of nonEuropean languages referring to natural phenomena, to more or less correspond to the level of Genus in Linnaean biological typology. ${ }^{1}$ It should be noted that the generic terms used by naturalists in their classifications are not complex or coined specifically for the purpose of labeling types of organisms as happens, for example, in the case of higher order categories, such as Chordates, Mammals or lower order ones, such as pedunculate oak, red oak, but rather they are simply adopted from casual, everyday language. ${ }^{2}$

The recognition of a certain level of schematicity/specificity of conceptions as basic in human cognition became one of the cornerstones of cognitive linguistics, especially cognitive semantics. Speakers of different languages tend to refer to material objects of cognition exhibiting good gestalt properties by using words representing conceptions of a similar, medium level of

1 This is by no means an infallible rule. In another work, the present author (Sokołowska 2018) demonstrates that a basic level in folk categorization can correspond, apart friom the generic (rat, bear, panther, fox), to practically any level in the scientific, Linnaean system of classification, i.e., class - fish, bird; order - bat, snake, lizard; family - weasel, hare, beaver, as well as, very commonly, species - dog (canis familiaris), wolf (canis lupus), cat (felis catus), horse (equus caballus), lion (panthera leo).

2 The etymology of common names of living organisms indicates that they often arise from casual observations of nature that focus on the most salient, cognitively relevant characteristics of the encountered phenomena. Good examples are the lexemes bear in English and its equivalent niedźwiedź in Polish; in both cases it is claimed that these were initially used as taboo words for the much feared animal and originally meant 'the brown one' (English) and 'the honey eater' (Polish). 
schematicity/specificity. These words activate ${ }^{3}$ semantic information of a number of the most relevant, outstanding characteristics of a given stimulus, and seem to be rather easily translatable from one language to another, even between unrelated languages, as was proved by Berlin and his associates' research into plant terminology used by the South-Mexican people of Tzeltal (cf. Lakoff 1987: 33). This research found that, in the case of living organisms, the basic level of categorization is one which is represented by words often corresponding to generic names in Linnaeus's biological taxonomy, such as rose, maple, horse, duck, which provides support to the Doctrine of Natural Kind Terms (cf. Lakoff 1987: 31-34). ${ }^{4}$ The validity of the translatability criterion seems to be supported by a comparison of certain first-choice nouns referring to certain phenomena (both natural and manmade) represented by the respective pictures in Figure 1. Speakers in most situations select such nouns to label the phenomena in their surroundings even if their language offers more general or more specific names (words) for the categories to which they may belong (e.g. plant, animal, fruit, furniture, tool, garment or pedunculate oak, Jack Russell terrier, McIntosh apple, kitchen knife, cargo trousers). Figure 1 illustrates a selection of such phenomena. In English and Polish the first-to-use names are, respectively, oak/dab, pine/sosna, dog/pies, cat/kot, elk/moose/łoś, apple/jabłko, table/stót, knife/nóż, trousers (AE pants)/ spodnie.

\footnotetext{
${ }^{3}$ In accordance with the basic assumptions of cognitive semantics, linguistic symbols do not convey meaning like containers but, rather, activate conceptual resources stored in language users' minds in terms of cognitive models / cognitive domains.

4 But see Note 1.
} 


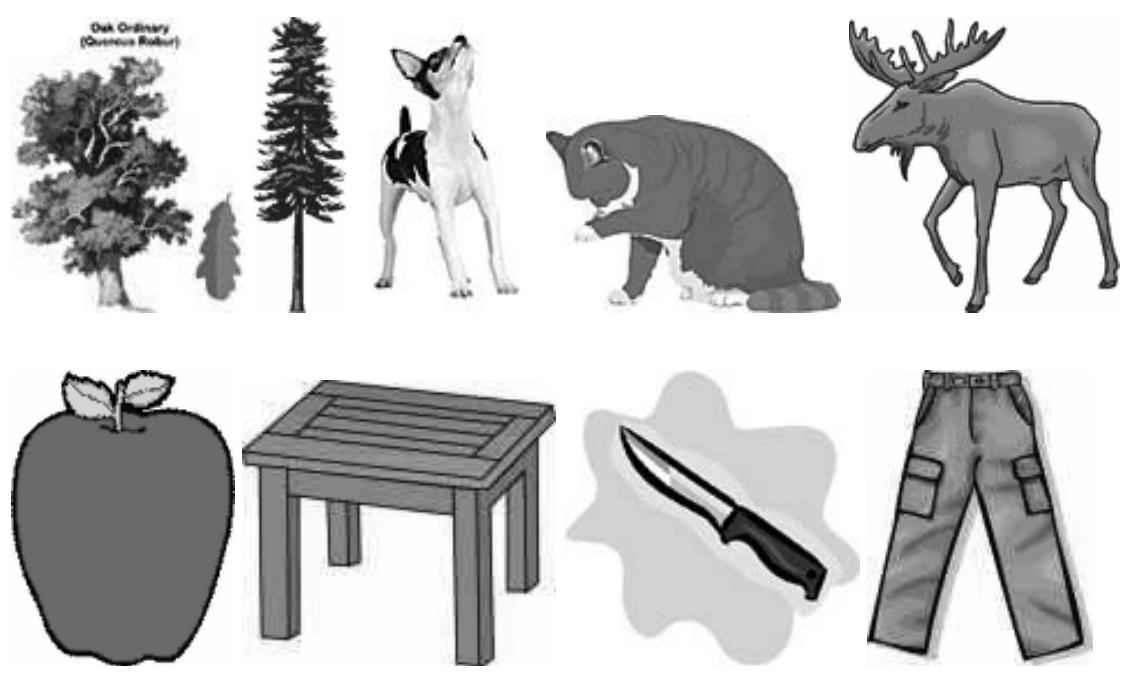

Figure 1

Examples of common stimuli eliciting basic terms (source: http://schools.clipart.com/)

As can be observed, the first-choice nouns functioning in both languages exhibit certain characteristics which were first recognized with regard to the nomenclature of basic (focal) colours (cf. Berlin and Kay 1969), the study of which resulted in establishing the so-called basic colour terms of a language. However, it is not only colours, but also a wide range of other stimuli that evoke linguistic symbols which are characterized by certain properties testifying to their special status in a given language, which qualifies them as basic terms of that language. These properties established for basic colour terms, but shared by terms referring to other phenomena are:

- a relatively simple morphological structure,

- native origin, 5

5 Nevertheless, in the case of certain phenomena that are not natural or indigenous to a certain area (exotic animals or plants or certain technical inventions) the criterion of native origin may not apply. For example, the basic level Polish word pług 'plow' is of German origin, as it refers to the device 
- broad reference not restricted to a small group of selected denotations,

- availability for all native speakers of a given language,

- early acquisition by children in their native language development.

As already mentioned, such terms are most readily used in daily life situations since they are the first ones to come to native speakers' minds.

As a consequence, basic terms can be expected to be the first to acquire by students learning a foreign language (constituting the basic vocabulary of that tongue), and to be matched relatively easily with other language counterparts. What is more, these counterparts are likely to exhibit the above-specified basic term characteristics, especially when the communities speaking the source and the target languages are not culturally distant.

The comparison of English and Polish words referring to the selected phenomena illustrated by Figure 1 confirms not only the symmetry between both languages with respect to naming them, but also the basic term properties of the respective words. It may be noted that the symmetry is not perfect and minor discrepancies may occur. For instance, some animals marked by one basic level word in one language may fall into different types represented by a number of basic level words in another language, like the schematic English noun deer, which in different contexts may correspond to three different lexemes jelen (red deer), sarna (roe deer) or daniel (fallow deer) in Polish, ${ }^{6}$ all of

adopted by Slavs, together with its name, from German farmer colonists who settled down in Slavic territories; also the common Polish words for animals such as tigers, giraffes, gazelles, crocodiles and such plants as bamboo, cedars, palm trees are nonnative and non-Slavic; they are direct loans from other languages.

6 A similar situation may be observed with the noun cherry (Cerasus) in English, which refers to any small, fleshy fruit containing a smooth, hard pit and ranging from yellow to very dark red (Webster's New World Dictionary of the American Language). Polish offers two basic level nouns distinguishing between the varieties of this fruit: wisnia (Cerasus vulgaris) for the smaller, very dark and sourish type (sour cherry); typically used for preserves, and czereśnia (Cerasus avium) for the larger, sweet kind (sweet cherry), irrespective of its colour; typically eaten raw. 
which belong to the basic level vocabulary. Likewise, the Polish noun łoś may be matched in English to moose or elk, although the use of either of the English lexemes is determined by the local dialect and may not necessarily reflect the distinction between the two species (Alces americana and Alces alces).

As the above-provided examples illustrate, the recognition of basic level categories arose from studying linguistic representations of physical objects constituting good gestalts in sensory perception. Such good gestalts can easily be distinguished among material phenomena observable in the world at large. However, the main issue addressed within the present paper is the investigation into whether the characteristics of the linguistic labels of tangible, conspicuous stimuli apply as well to lexemes referring to other, nonmaterial phenomena, in whose case it is not possible to talk of gestalt properties of physical nature. Namely, what seems to deserve interest is the issue of the basic level categorization applied to actions, stimuli typically described by verbs. The question is whether basic words describing certain actions in different languages represent conceptions of comparable levels of generality. Do basic verbs in one language easily evoke other language counterparts of identical or almost identical semantic scopes, as is the case with nouns naming natural phenomena at the generic level?

Lakoff, in his fundamental work Women, Fire and Dangerous Things (1987), mentions basic motion verbs (run, walk) and basic locative verbs (stand, sit, lie) without, however, clearly specifying whether they can be considered symbols of basic level categories recognized by the mind. Nevertheless, these English verbs meet the above-specified criteria of basic terms. Most of them are subject to archaic inflection by ablaut, which additionally testifies for their native, Anglo-Saxon origin. In another work, however, Metaphors We Live By (1980: 77-86), Lakoff and Johnson posit the notion of experiential gestalts - well defined models of various, not necessarily physical, phenomena. As examples, they quote the notions of war, argument, journey, causation, which are events comprising a series of interrelated activities organized along the temporal axis. These experiences, in 
turn, give rise to conceptions subsequently stored in the mind as the Idealized Cognitive Models. It may, then, be assumed that processes symbolized by physical action verbs, which in principle involve the cognitive domain of time, can also constitute such mental gestalts. What is more, action verbs, just like nouns, can represent respective phenomena with varying levels of specificity/schematicity, e.g. move-walk-amble, consumedrink-gulp, perceive-look-stare, one of which (the middle, in these instances) appears to be optimal from the point of view of human cognition. It seems that, just like in the case of physical objects, basic physical activities commonly performed by practically all human beings should give rise to mental gestalts, similar to those evoked by nominal expressions. Figure 2 provides examples of such basic experiences, which seem to be shared by all humans irrespective of their culture and the language they speak: consuming food, moving in three-dimensional space, moving in water, and destroying things. It should be noted that very young children (as young as two years old) are normally able to name many such experiences; as indicated by Clark (1990), with verbs referring to simple physical activities constituting about $25 \%$ of their total vocabulary.
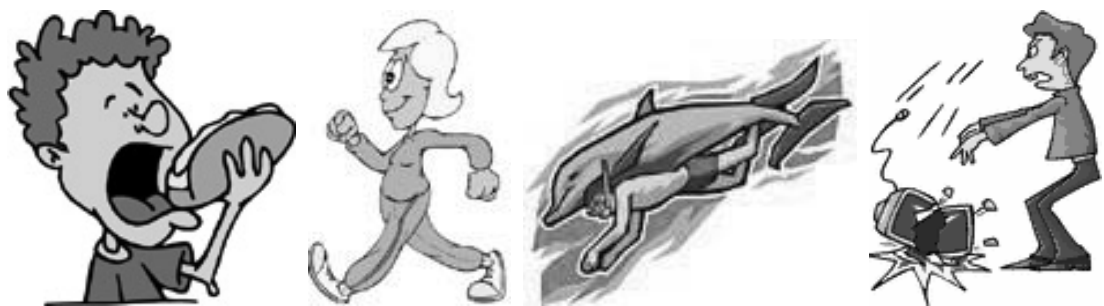

consuming food, moving in space, moving in water, destroying things

Figure 2

Examples of basic experiences shared by all humans (source: http://schools.clipart.com/) 
Given the corporal and physically experiential nature of the illustrated activities, it might be expected that, just as in the case of objects and nouns, the recognition of the basic level of processes and verbs should be cross-linguistic, especially in the case of the two languages taken into consideration within the present work: English and Polish, both of which are Indo-European and both of which are spoken by culturally proximate communities. However, a closer look at the functioning of lexemes referring to the respective experiences reveals the fact that this expectation may not be fulfilled. Table 1 below illustrates the results of an investigation into the issue.

Table 1

English and Polish basic verbs referring to common physical experiences

\begin{tabular}{|l|l|l|}
\hline \multicolumn{1}{|c|}{ Experience } & \multicolumn{1}{c|}{ English } & \multicolumn{1}{c|}{ Polish } \\
\hline consuming food & eat & jeść \\
\hline moving in space & go & $\begin{array}{l}\text { iść (telic) / chodzić (atelic) } \\
\text { jechać (telic) }\end{array}$ \\
\cline { 2 - 3 } & walk & iść / chodzić \\
\hline \multirow{2}{*}{ moving in/on water } & swim & płynać (telic) / pływać (atelic) \\
\cline { 2 - 3 } & sail & płynać \\
\cline { 2 - 3 } & flow & pływać \\
\cline { 2 - 3 } destruction & float & $\begin{array}{l}\text { łamać } \\
\text { tłuc } \\
\text { rozbić }\end{array}$ \\
\hline & break & $\begin{array}{l}\text { rwać } \\
\text { drzeć }\end{array}$ \\
\cline { 2 - 3 } & $\begin{array}{l}\text { break/tear } \\
\text { tear }\end{array}$ & \\
\hline
\end{tabular}

7 Given that Polish offers two basic infinitival forms for its verbs (perfective and imperfective), it is always necessary to decide which of them to use for quotation; as a matter of fact even dictionary authors are not always consistent in this respect. In the table cell above the infinitive rozbic is perfective, while the remaining verbs (łamać, tłuc) are imperfective. 
Table 1 lists English verbs standing for the basic physical processes discussed here and presents their Polish equivalents. Indeed, in the case of some activities, like consuming food, the specificity and schematicity levels of conceptions represented by basic verbs in English and Polish seem to be comparable. This means that both eat and its equivalent jeś $c^{8}$ represent concepts involving a similar (neither very high nor very low) number and array of cognitive domains, i.e. lower order notions activated in the semantic scopes of the predicates (cf. Langacker 1988), such as those of a living organism equipped with an oral cavity, biological needs, food put into that cavity, swallowing, hunger, satiation, taste and perhaps a few other, minor notions. It should be noted that such details as the precise kind of organism, form of food, method of taking and processing it, and mode of swallowing are not specified by the verbs alone. These details only emerge in a specific context which activates relevant cognitive domains, e.g. to eat soup (the conceptions of liquid, a bowl, a spoon), an apple (the conceptions of teeth, biting, chewing, crunching), ice-cream (the conceptions of a tongue, licking), a steak (the conceptions of a plate, knife, fork, teeth, biting, chewing), or they may be provided by more specific verbs of a subordinate level, e.g. to gnaw, to chew, to lick etc. Needless to say, the contents of cognitive models evoked by complex predicates of the verb + object type are, to a high degree, determined by experience.

Nevertheless, in the case of verbs referring to basic physical experiences other than eating such neat correspondences between English and Polish are impossible to find. The discrepancies are illustrated by Table 1 . As already indicated, apart from eating, the experiences considered are those of moving in space, moving in/on water, and destroying. The basic Polish verb referring to the most common way of moving in three-dimensional space (in the telic form iść and the atelic - chodzicic) is translated

8 Both verbs derive from the same Proto-Indo-European stem *ed-meaning 'to eat'.

9 This particular verb, like a number of other ones in Polish also has the atelic iterative infinitival form chadzać 'go from time to time'. 
by dictionary authors (The Great Polish-English Dictionary by Jan Stanisławski and the PWN-Oxford Polish-English Dictionary) into two basic English verbs $g^{10}$ and walk, which differ considerably from each other in regard to the specificity/schematicity level of the conceptions they represent. Name-ly, the verb walk (like iść, but unlike go) necessarily involves the notion of legs positioned vertically with respect to the ground and pendular movement as primary cognitive domains. This is the reason why the Polish expression iść pieszo (literally 'walk on foot') has a pleonastic flavor: the notion of moving legs in a specific manner seems to be activated by both elements of the phrase. The English verb go is much more schematic than the verb walk and its Polish counterpart iść, and refers to practically any movement in space, without specifying the method, medium, speed, or the possible use of a vehicle. The details are, consequently, provided by the context, e.g. to go on foot, by bike, by plane, by car, by train, on skis, on horseback, etc. Most of the enumerated senses must be translated into Polish by means of the basic movement verb jechać, which involves the cognitive domain of a means of transport as primary. Jechać, in turn, does not seem to have an exact English counterpart, as the closest one, go, does not require the domain of any kind of vehicle being activated, and is thus far more schematic. The Polish verb of a schematicity level comparable to that of go seems to be udać się 'resort to', but it involves certain cognitive domains that go does not primarily activate (eminence, respect, official register), and is generally used to describe the official travels of important, estimable persons.

10 It needs to be mentioned that the parameter which in English plays an important role in selecting a basic verb of movement is directionality (toward or away from the speaker). It seems that the presented generalizations concerning the verb go also apply to its counterpart marking the opposite spatial orientation come, apparently representing a similar level of schematicity as its antonym. Polish does not offer two distinct verbs to describe movement toward or away from the speaker. The directionality of movement towards the speaker may be marked by a prefix attached to the stem iść, as in przyjść 'come' or pójść 'go out/away'. 
The above described lack of symmetry between the English and Polish basic verbs of motion may sometimes give rise to difficulties in understanding the exact sense of certain expressions for foreign language learners. This may be illustrated by the problems caused to Polish learners of English by the interpretation of a certain situation described in a question eliciting exercise, which is That man with a pack on his back went into the field and died. Students are supposed to find out what really happened by asking only yes-no questions. In doing so, Poles invariably tend to think of a person walking or riding across land, and the final explanation, that the story features an unfortunate paratrooper whose parachute did not open, comes as a surprise to them. The conclusion that can be drawn is that the English and Polish basic verbs of physical movement in space represent conceptions of inconsistent specificity/schematicity levels.

A similar situation can be observed in the case of the basic verbs representing movement in/on water. This time, however, it is Polish that offers a lexeme of a much higher schematicity level than its basic level English counterparts. Again, Table 1 illustrates the issue. The Polish verb ptynace, in the telic form, is sufficiently schematic to represent not only the movement of an object of any kind, animate or not, in water or on its surface, but also the movement of water (or any other liquid) itself, as in Strumien płynie przez łake 'The stream flows across the meadow'. It is also maximally schematic as regards the method employed by an object engaged in its movement in/on water. The atelic form of the verb, pływać may refer, apart from the activities represented by its telic counterpart, also to floating of an object on the surface of the water without necessarily covering any distance. ${ }^{11}$

By contrast, English has created basic verbs referring to the forms of movement connected with water which represent much more specific cognitive models. Thus, covering distance in/on

\footnotetext{
11 The telic form is not possible in such contexts, since what the atelic verb describes is a stable property rather than activity of an object; that property being its floatability.
} 
water due to the movement of a body or its parts is represented by the verb swim, which activates the cognitive domain of a living organism as a primary one. The movement in/on water executed by means of the force of wind, the power of muscles attached to oars, the power of an engine, or even the movement of water itself is metonymically symbolized by the verb sail, primarily activating the cognitive domain of a vessel propelled by wind power. The ability to stay on the surface of water not necessarily connected with covering distance is represented by the basic verb float, while the directed movement of water itself is represented by yet another basic verb, flow. Again, the two considered languages have not produced basic verbs referring to specific basic experiences of comparable schematicity/specificity levels. A possible explanation of this difference may be linked to different cultural experiences of contact with water. Unlike the mostly land-locked Slavs, the English have a long maritime tradition that may have created the need for more concise and precise ways of referring to movement connected with water.

Another basic experience symbolized by basic verbs in English and Polish which differs in the two languages with regard to their schematicity/specificity levels is that of destruction, which, as is well known, may be accomplished in a number of different ways. This discrepancy is again illustrated by Table 1 . From a cognitive standpoint, this experience entails purposeful destruction executed by means of physical force, which is also a prototypical instance of causation (cf. the model specified by Lakoff 1982: 47-48, 1987: 54-55). Such an instance clearly pictures a physical action consciously executed by a human, with well-distinguished participants: the agent (performer) and the patient (entity affected), evident energy transfer resulting in changes occurring in the structure of the patient; the action being willed and controlled by the agent, accomplished with bodily and eye contact of the agent with the patient. The basic and commonly used English verb break referring to prototypical (as 
well as non-prototypical ${ }^{12}$ ) destruction is highly schematic, and does not specify the method or the nature of the object of such activity. Polish, just like in the case of go, does not offer an exact counterpart that would be of a comparative schematic level. The verb niszczyć 'destroy' seems to be quite close, but it is not a first-choice verb in describing situations where the objects and the results of destruction (the entities no longer constituting integrated wholes) are specified, with, e.g., sticks, fingernails, pencils, keys, cups, windows, wax seals etc. involved. Besides, unlike break, niszczyć does not necessarily refer to the physical disintegration of an object, but may just as well describe the unwelcome altering of its appearance by soiling, as in Graficiarze zniszczyli mi płot 'Graffiti taggers destroyed my fence'. Therefore, the English verb corresponding to niszczyć is the superordinate level destroy, not break, as duly confirmed by both Polish-English dictionaries mentioned above.

The basic verbs of destruction developed by Polish are much more specific than break, as they involve the cognitive domains of concrete types of objects and methods of destruction as primary ones. The English-Polish versions of the above mentioned dictionaries (Jan Stanisławski and the PWN-Oxford) provide all of the following as translations of the English lexeme in question: łamac describing the destruction of objects with a rigid structure, whether two- or three-dimensional, such as a match, a seal, ice on a river. Another Polish basic destruction verb, tłuc, is even more specific, as it refers to destroying objects that are not only rigid, but also made of specific material (glass or porcelain). A relevant cognitive domain in this case seems to be the sound accompanying the action, as the destruction of plastic cups, for example, is described by łamać, not tłuc, which would be used if the cups were made of china or glass. There is another common Polish verb, rozbic, often used in the same contexts as

\footnotetext{
12 Non-prototypical destruction is involved in cases when causing the disintegration of a patient is incidental, unwilled, considerably delayed in time, caused indirectly, not caused by means of immediate energy transfer, or when the agent is non-human or unspecific, and the patient undergoes a change that is undetectable to a casual witness.
} 
ttuc, but it does not seem to involve the cognitive domain of a clinking sound, as it occurs in the phrase rozbic atom 'to split an atom'. Besides, it has a morphologically complex structure, which casts doubts on its qualification as a basic term. Nevertheless, it is the latter verb that is used in Polish in contexts that involve destruction in a metaphorical sense, e.g. rozbic rodzine 'to break up a family', rozbic spisek 'to thwart a scheme', in which activating the cognitive domain of sound is unnecessary.

However, it would be far-fetched to claim that English generally offers a more schematic basic verb of destruction in comparison to Polish, and that the detailed information about the precise kind of destruction in the former language is always provided by cognitive domains represented by the object noun (whose role is to activate the relevant lower order conceptions, which in Polish is also the task of the verb). The situation is complicated by the fact that the Polish specific verb of destruction rwać presupposes a flexible, rather soft object (such as string, paper or fabric) and corresponds to the English verb break only in some contexts. It seems that such objects can be broken when they are one-dimensional (break a string, break bonds), otherwise they are torn (tear up a letter, tear a sheet, tear one's jeans). Objects, which apart from some length, are also characterized by some width, appear to be associated with another Polish basic verb of destruction drzeć, whereas rwać does not presuppose concrete dimensionality and may be used to describe the destruction of both one- or two-dimensional objects alike. The third commonly recognized dimension, depth, albeit physically recognizable in flexible entities that can be broken or torn, does not seem to be relevant in the semantic scopes of the considered lexemes, either in English or in Polish.

As can be observed, the semantic fields of destruction and movement have been tackled very differently by English and Polish, and in the above-discussed cases it is the Polish verbs that provide a higher level of detail about the processes to which they refer (with a notable exception of describing movement in/on water). Of course, the more schematic semantic "content" 
of a verb in either language does not result in lower effectiveness as regards expressing information about a given process. All destruction verbs are transitive and together with their objects they give rise to conceptual blends ${ }^{13}$ in which the relevant cognitive domains specifying the manner and effects of an action may be provided by the nouns. For example, the cognitive domain of fragility, as in to break a cup is, in English, imported by the object. Polish, by contrast, offers the much more specific verb ttuc in the corresponding phrase (s) ttuc ${ }^{14}$ filiżanke and seems to provide the specific semantic import from two sources, as the conception of fragility is found in the semantic scopes of both phrase members. It has already been mentioned that the Polish expression iść pieszo, which literally means 'walk on foot,' sounds somewhat pleonastic when it refers to physical movement. The use of the adverb pieszo 'on foot' is, however, justified when it is not clear whether the verb isć is used in a physical or metaphorical sense, as in Janek poszedł do szkoły 'John went to school'; it disambiguates such a statement, clearly indicating that the physical sense of poszed 'went' is at issue there.

The fact that verbs, as relational predicates, typically occur in complex constructions (thus giving rise to conceptual blends) seems to explain the fact that languages tend to preserve a similar level of schematicity/specificity of nouns referring to independent objects (construed as things, i.e. as regions in certain cognitive domains, cf. Langacker 1987), but assume a rather free approach to this parameter pertaining to processes, which relate such independent phenomena to either other phenomena (transitive verbs) or to certain elements of the setting, profiled or unprofiled within an utterance (intransitive verbs). It does not seem to matter much in regard to the contents of the resulting conceptual blend which element of a phrase is the provider of a relevant cognitive domain. What seems to be achieved with a higher degree of verb schematicity is a certain economy in

13 The notion of conceptual blends is understood in the sense presented by Turner and Fauconnier (1995).

14 The prefix $s$ - marks the completedness (perfectiveness) of the action in question. 
communication, namely in avoidance of doubling the information concerning the details of a given process that is already provided by an object or an adverbial phrase.

As the presented survey suggests, the assumption of the universality of the basic level of categorization, corroborated by the comparison of nominal expressions, which has given rise to the Doctrine of Natural Kind Terms is observed only to a limited degree in the case of basic verbs, even though it can be claimed that the experiences they symbolize are indeed shared by all humans. It seems that different languages quite arbitrarily, though in all probability not haphazardly, establish different basic levels of categorization with regard to processes, at least the ones selected for the present study. In conclusion, it can be stated that elementary activities (processes) do not seem to constitute cognitive stimuli imposing themselves on human cognition in a similar manner to things. In the case of processes, a much more important role appears to be performed by the freedom of imagery that allows for choosing the levels of schematicity or specificity which are not necessarily the same in all speech communities. Whatever the reasons for this variability, the languages of specific communities duly conventionalize the levels of generality optimal for their speakers. Consequently, the so-established verbs adjust themselves to the respective lexical systems and contribute to the creation of conceptual blends that need to be communicated via language.

\section{References}

Berlin, Brent, Paul Kay (1969). Basic Color Terms: Their Universality and Evolution. Berkeley - Los Angeles: University of California Press.

Clark, Eve V. (1995). The Lexicon in Acquisition. Cambridge: Cambridge University Press.

Evans, Vyvyan (2019). Cognitive Linguistics: A Complete Guide. Edinburgh: Edinburgh University Press.

Lakoff, George, Mark Johnson (1980). Metaphors We Live By. Chicago and London: The University of Chicago Press. 
Lakoff, George (1982). Categories and Cognitive Models. Linguistic Department and Cognitive Science Program: University of California at Berkeley.

Lakoff, George (1987). Women, Fire and Dangerous Things. Chicago: The University of Chicago Press.

Langacker, Ronald W. (1987). "Nouns and verbs". Language 63: 5394.

Langacker, Ronald W. (1988). "A view of linguistic semantics". In: Brygida Rudzka-Ostyn (ed.). Topics in Cognitive Linguistics. Amsterdam - Philadelphia: John Benjamins, 44-90.

PWN Oxford Wielki słownik angielsko-polski. English-Polish Dictionary / Wielki słownik polsko-angielski. Polish-English Dictionary (2002). Wydawnictwo Naukowe PWN.

Sokołowska, Olga (2018). "Levels of categorization in animal idiomatic expressions". Beyond Philology 15/1: 69-86.

Stanisławski, Jan (1970). Wielki słownik polsko-angielski / Wielki słownik angielsko-polski. Warszawa: Państwowe Wydawnictwo "Wiedza Powszechna".

Turner, Mark, Giles Fauconnier (1995). "Conceptual integration and formal expression". Metaphor and Symbolic Activity 10/3: 183-204.

Webster's New World Dictionary of the American Language (1979). William Collins Publishers, Inc.

Olga Sokołowska

ORCID iD: 0000-0002-4722-113X

Instytut Anglistyki i Amerykanistyki

Uniwersytet Gdański

ul. Wita Stwosza 51

80-308 Gdańsk

Poland

olga.sokolowska@ug.edu.pl 